Sains Malaysiana 49(1)(2020): 19-27

http://dx.doi.org/10.17576/jsm-2020-4901-03

\title{
PEGylated Oleic Acid-Lecithin Liposomes (POLL) for Anticancer Drug Delivery
} (Liposom Asid Olik-Lesitin BerPEG (POLL) untuk Penghantar Ubat Anti Barah)

\author{
Vicit Rizal Eh SuK*, Ivy Chung \& Misni MisRan
}

\begin{abstract}
Cancer is a major health issue, conferring to more than 14.5 million deaths worldwide. Liposomes, self-assembly amphiphilic bilayer molecules, served as excellent alternative vehicles due to their ability to encapsulate both hydrophobic and hydrophilic anticancer drugs. Conventional liposomes, comprised mainly phospholipids are costineffective, unstable, and easily degraded by the external environment. In this study, we introduced PEGylated oleic acid-lecithin liposomes constructed by using C-18 monounsaturated fatty acids (oleic acid) and soy lecithin, in the presence of DOPEPEG2000 in pH7.4, above their glass transition temperature, $\mathrm{T}_{g}$, by employing the simple thin layer lipid hydration method. FTIR spectrum of oleic acid, soy lecithin, and DOPEPEG2000 was studied. The average particle size without further mechanical interference was $1102.3 \mathrm{~nm}$ while the zeta potential value was $-18 \mathrm{mV}$, which is compatible with the zeta potential of the red blood cell. The polydispersity index (PDI) was reduced by $46.2 \%$ with the incorporation of the DOPEPEG2000. The morphological study using OPM showed the presence of spherical shape liposomes that exhibit the birefringence effect under the light field and Maltese cross under the dark field. Encapsulation of folinic acid, methotrexate, doxorubicin, or irinotecan resulted in greater than $75 \%$ encapsulation efficiency (EE). Half-maximal inhibitory concentration, $\mathrm{IC}_{50}$, was significantly reduced in POLL as compared to free anticancer drugs. Our data demonstrate POLL may be a promising alternative vehicle to deliver various anticancer drugs to targeted tumour sites.
\end{abstract}

Keywords: Anticancer drugs; liposomes; oleic acid; POLL; soy lecithin

\section{ABSTRAK}

Barah merupakan isu kesihatan utama yang menyebabkan lebih 14.5 juta kematian di seluruh dunia. Liposom, iaitu molekul swabentuk dwilapis merupakan penghantar alternatif terbaik berikutan kebolehannya untuk mengkapsulkan ubatan anti barah hidrofobik dan hidrofilik. Liposom yang lazimnya diperbuat daripada fosfolipid adalah tidak efektif daripada segi kos, tidak stabil dan mudah terurai oleh persekitaran luar. Dalam kajian ini, kami memperkenalkan liposom asid olik-lesitin berPEG yang terdiri daripada asid lemak tak tepu C-18 (asid olik) dan lesitin soya, dengan kehadiran DOPEPEG2000 dalam pH7.4, pada suhu lebih tinggi daripada suhu peralihan gelas $\mathrm{T}_{g}$, menggunakan metod hidrasi lapisan nipis lipid. Spektrum FTIR asid olik, lesitin soya, dan DOPEPEG2000 juga turut dikaji. Purata saiz partikel adalah $1102.3 \mathrm{~nm}$ manakala keupayaan zeta adalah $-18 \mathrm{mV}$, sesuai dengan keupayaan zeta sel darah merah. Indeks polisebaran telah berkurang sebanyak 46.2\% dengan penambahan DOPEPEG2000. Kajian morfologi menggunakan Mikroskop Optikal Pengutuban menunjukkan kewujudan liposom berbentuk sfera yang menghasilkan kesan dwibiasan pada medan cerah dan silang Maltese pada medan gelap. Pengkapsulan asid folinik, metotreksat, doksorubisin atau irinotecan menghasilkan lebih 75\% kecekapan pengkapsulan. Kepekatan separa rencatan, $\mathrm{IC}_{50}$, telah berkurang dengan signifikan pada POLL berbanding ubatan anti barah. Data menunjukkan POLL mungkin berpotensi untuk menjadi penghantar ubatan anti barah ke tempat yang ditujui.

Kata kunci: Asid olik; lesitin soya; liposom; POLL; ubatan anti barah

\section{INTRODUCTION}

More than 14.1 million new cancer cases (Bray \& Shield 2017) were reported globally and World Health Organization (WHO) projected that the new cases of cancer would rise to 21.4 million cases by 2030 (Beaglehole et al. 2011). The common sites of new cancer cases reported are lung, breast, cervix, prostate, colorectum, stomach, liver, and oesophagus. Statistics from the National Cancer Council of Malaysia (MAKNA) reported that the deadliest lung cancer kills more than $95 \%$ of patients within 5 years of diagnosis (Lai \& Dewi 2015). Cancer can be explained as an uncontrolled production of cells in the body disregarding normal cell division and potentially invading to other parts of the body (Martinez-Pastor \& Mostoslavsky 2012).

The growth of cancer cells is generally divided into four numerical stages, which are stage I, where cancer is relatively small, stage II for cancer that invades into lymph nodes close to the tumour, stage III for cancer spreads into 
surrounding tissues, and stage IV for cancer that spreads to other organs. Cancer staging is one of the most important parameters used to specify prognosis, to assess the treatment results, to evaluate the similarities between different cases, to diagnose the cancer trends, and to design a suitable therapy to treat cancer (Dollinger et al. 2002).

Various approaches are available to treat patients with cancer, such as tissue removal through surgery (Bae et al. 2013; Dollinger et al. 2002; Feng et al. 2016; Wu 2013), radiotherapy (Bae et al. 2013; Chun et al. 2017; Vorbeck et al. 2017; Yom 2015), and chemotherapy (Dollinger et al. 2002; Gupta et al. 2017; Heshmat \& Eltawil 2017; Lewis \& Bloomston 2016; Vlasova et al. 2014). Combination therapy of surgery or radiotherapy with chemotherapy is normally taken to achieve the synergistic effect. Unfortunately, most chemotherapy drugs cause substantial damage to the organs such as heart, lung, or kidney, and may lead to secondary cancer due to the occurrence of cell mutation during chemotherapy (Dollinger et al. 2002). Even though this combinational mechanism is successful in treating various cancer, it still causes more than 14.5 million deaths worldwide in 2014 (Heshmat \& Eltawil 2017), mainly due to insufficient delivery of chemotherapeutic drugs to the tumour target tissue or due to severe and harmful toxic effects on normal cells (Anderson et al. 2013).

Many drug carriers from colloidal particulates (Immordino et al. 2006) such as micelles (Lasic 1992; Mehta \& Jindal 2013; Stevenson-Abouelnasr et al. 2007), emulsion (Ninomiya et al. 2016), and liposomes (Banerjee et al. 2004; Bansal et al. 2016; Eh Suk \& Misran 2016; Napia et al. 2018; Sercombe et al. 2015; Suzuki et al. 2012) had been developed to deliver chemotherapeutic drugs to the targeted tumours and hence improve their therapeutic effects. Liposomes gain the most attention due to their ability to cross cell membranes and to deliver anticancer drugs of different solubility. Since the discovery of liposomes in the 1970s (Gebicki \& Hicks 1973), many amphiphilic molecules especially phospholipids had been used in formulating liposomes as a carrier for anticancer drugs. In this study, two amphiphilic molecules, which were soy lecithin containing more than $95 \%$ phosphatidylcholine and oleic acid were used to prepare liposomes (Hamzah et al. 2017). The formation and properties of the liposomes (Fameau et al. 2014) are highly governed by the types and length of the hydrophobic tails, ionization of the hydrophilic groups, the existence of functional groups on the alkyl chain, and the binding with counter-ions. The mixture of these materials was less explored due to the instability of liposomes prepared by the fatty acid or phospholipid alone. However, incorporation of stealth molecule (Hsu et al. 2014; Jøraholmen et al. 2017; Lehtinen et al. 2012; Suzuki et al. 2012), (1,2-dioleoylsn-glycerol-3 phosphoethanolamide -N-[methoxy (polyethylene glycol)-2000]) in the formulation enhanced the stability of liposomes (Hsu et al. 2014), which expected to provide a protective coating from reticuloendothelial system (RES) and prolong the blood circulation half-life (Lehtinen et al. 2012).

\section{Materials AND Methods}

Oleic acid ( $90.0 \%$ purity) and pharmaceutical grade sodium hydroxide were purchased from Fluka, while hydrochloric acid was purchased from Sigma Aldrich. DOPEPEG2000 (1,2-dioleoyl-sn-glycerol-3 phosphoethanolamide $-N$-[methoxy (polyethylene glycol)-2000]) was obtained from Avanti Polar Lipids Inc. and pharmaceutical grade chloroform (99.0\% purity) was purchased from Merck. L- $\alpha$-lecithin from soybean ( $97.7 \%$ purity) was purchased from Calbiochem. Dulbecco's Modified Eagle Medium (DMEM), fetal bovine serum (FBS), and PenicillinStreptomycin-Glutamine were purchased from Thermo Scientific. All solutions were prepared by using deionized water with $18.2 \mu \mathrm{S} \mathrm{cm}^{-1}$ deionized by Barnstead NANO pure ${ }^{\circledR}$ Diamond ${ }^{\mathrm{TM}}$ ultrapure water system. All experiments were carried out at $30 \pm 1{ }^{\circ} \mathrm{C}$ unless otherwise stated.

\section{Spectroscopic AnALYsis}

Infrared spectroscopy measurements of oleic acid, soy lecithin, and DOPEPEG2000 were analysed with Fourier Transform Infra-Red Spectroscopy (FTIR) Spectrum 400 (Perkin Elmer, USA) in Department of Chemistry, University of Malaya. One hundred $\mu \mathrm{g}$ of samples $(0.2 \%$ $\mathrm{w} / \mathrm{w})$ were added to potassium bromide $(\mathrm{KBr})$ in the mortar and ground to homogeneous (Zofka et al. 2013). The mixture was then carefully sandwiched in the $13 \mathrm{~mm}$ evacuable potassium bromide dies (Perkin Elmer, USA) and transferred onto pistil of the manual hydraulic press (Specac, UK) followed with the manual pump until the pressure reached 10 tons to produce the sample disk of $\sim 13$ $\mathrm{mm}$. After a minute, the pressure was released and the sample disk was transferred to the IR sample holder. The disk was then scanned for sixteen scans per sample within the wavenumbers range of 400 to $4000 \mathrm{~cm}^{-1}$ at room temperature. IR spectroscopy of the sample was matched to the wavenumbers of every species.

\section{Differential SCANNing CALORImetry (DSC)}

Thermal behaviour of oleic acid, soy lecithin, and DOPEPEG2000 were analysed using DSC Q20 Difference Scanning Calorimetry (TA Instruments, USA) in the Department of Chemistry, University of Malaya. About 5 mg of the sample (Duh et al. 2016; Menon et al. 2015) was weighed carefully into the $40 \mu \mathrm{L}$ Tzero aluminium pans, covered with the Tzero Hermetic Lid, and sealed carefully using a Tzero sample press. An empty $40 \mu \mathrm{L}$ Tzero pans covered with Tzero Hermetic Lids and sealed in the same manner was used as reference pan. Both sample and reference were then transferred onto the platform in the DSC cell. Nitrogen gas (Air Products Sdn. Bhd., Malaysia) with flow rates of $50 \mathrm{~mL} \mathrm{~min}^{-1}$ was used as the atmospheric gas. The DSC was set to equilibrate at $-30^{\circ} \mathrm{C}$ for one minute with the aid of liquid nitrogen and ramped to $150^{\circ} \mathrm{C}$ with ramping rates of $2^{\circ} \mathrm{C} \mathrm{min}{ }^{-1}$. Glass transition temperature of the samples was identified from the thermograms. 
Preparation of PEGylated Oleic Acid-Lecithin LIPOSOME (POLL)

Oleic acid, soy lecithin, and DOPEPEG2000 were dissolved in $5 \mathrm{~mL} \mathrm{CHCl}_{3}$ and homogeneously mixed up using ultrasonicator (JEIO, Japan) for $10 \mathrm{~min}$. The mixture was placed under reduced pressure using a rotary evaporator (Büchi ${ }^{\circledR}, \mathrm{USA}$ ) to remove $\mathrm{CHCl}_{3}$. POLL was prepared by employing the thin lipid hydration technique (Tan \& Misran 2013; Teo et al. 2011), where the resultant thin lipid mixture by using warm phosphate-buffered saline (PBS). The solution was adjusted to $\mathrm{pH} 7.4$ using $0.05 \mathrm{~mol} \mathrm{dm}^{-3} \mathrm{HCl}$ or $\mathrm{NaOH}$ and marked up to $10 \mathrm{mmol} \mathrm{dm}^{-3}$ using PBS pH7.4.

\section{Optical Polarizing Microscope (OPM)}

The presence of the POLL was observed by employing an optical polarizing microscope (Leica, Germany) at 50× magnification and analysed using Leica QWin image analysis software. A clean glass slide was used to place $200 \mu \mathrm{L}$ of sample and covered with a coverslip. Immersion oil was dropped onto the coverslip for viewing purposes. The sample was observed under the light phase to observe the birefringence effect while the dark phase was used to detect the Maltose cross of liposomes.

\section{Determination of Particle Size and Zeta Potential}

Zetasizer NanoZS (Malvern Instruments Ltd., United Kingdom) equipped with a $4 \mathrm{~mW} \mathrm{He-Ne} \mathrm{laser} \mathrm{at} 633 \mathrm{~nm}$ was used to measure zeta potential and particle size of POLL. One $\mathrm{mL}$ of sample was injected into polycarbonate with gold plated folded capillary cell electrodes to measure zeta potential while four-sided clear fluorescent quartz cuvette was used to measure the particle size. All measurements were carried out in triplicate at $30^{\circ} \mathrm{C}$.

\section{ENCAPSULATION EFFICIENCY}

Thin lipid film of POLL was hydrated with $1 \mathrm{mM}$ solution of irinotecan, methotrexate, leucovorin, or doxorubicin and adjusted to $\mathrm{pH} 7.4 \mathrm{using}$ an appropriate amount of $0.05 \mathrm{~mol}$ $\mathrm{dm}^{-3} \mathrm{HCl}$ or $\mathrm{NaOH}$. Vivaspin $10 \mathrm{kDa}$ molecular weights cut off (Sartorius Stedim, Belgium) centrifuged at 1500 rpm was used to discard the free drugs in the solution (Ohnishi et al. 2013). The amount of free drug was then quantified from the calibration curve that generated from the absorbance of Varian Cary 50 UV-Visible spectrophotometer against the concentration of anticancer drug at $30^{\circ} \mathrm{C}$. Encapsulation efficiency (\%EE) of drugs can be calculated using the equation $\% \mathrm{EE}=[100-(100 \mathrm{~F} / \mathrm{T})]$ where $\mathrm{F}$ is the amount of free drug, while $\mathrm{T}$ is the total of the drug in the solution.

\section{Cell Culture}

Homo sapiens lung carcinoma cell lines A549 (ATCC $\mathbb{R}$ CCL-185 ${ }^{\mathrm{TM}}$ ) was provided by Dr. Lee Poh Foong and Dr.
Teoh Boon Yew from Lee Kong Chian Faculty of Engineering and Science, UTAR. Cell cultures studies were conducted in Translational Core Laboratory, Faculty of Medicine, University of Malaya. A549 was grown in DMEM supplemented with 10\% FBS and penicillinstreptomycin-glutamine. The cell was incubated in $5 \% \mathrm{CO}_{2}$ at $37^{\circ} \mathrm{C}$. The MTT (3-[4,5-dimethylthiazol-2-yl]-2,5diphenyltetrazolium bromide) assay technique was employed to quantify the changes in the number of cells regarding the cytotoxicity of the medium (Sun et al. 2015; Yang et al. 2015). One hundred $\mu \mathrm{L}$ of $0.5 \times 10^{5}$ cells $\mathrm{mL}^{-1}$ were seeded in 96 wells plate in triplicates and allowed to attach for $24 \mathrm{~h}$. The cells then treated with POLL encapsulating anticancer drugs at varied concentrations by using POLL as a negative control. POLL showed comparable cytocompatibility, which is agreeable with many published reports suggesting that blank phospholipid liposome does not show any toxic effect on the cell lines (Sun et al. 2015). After $24 \mathrm{~h}$, cells were rinsed with PBS and treated with 5 $\mathrm{mg} \mathrm{mL} \mathrm{mL}^{-1}$ MTT solution and incubated for $4 \mathrm{~h}$ followed by the addition of dimethyl sulfoxide (DMSO). The cells were further incubated for $12 \mathrm{~h}$ and the absorbance of the cells was measured using multi-mode microplate reader (SpectraMax ${ }^{\circledR}$, USA).

\section{RESUlts AND Discussion}

\section{FTIR ANALYSIS}

FTIR is widely explored to deliver spectral information indicating some similarities from one to another during raw material analysis, quality control, characterization, and identification of extract product in the fat and oil industry. FTIR spectra of DOPEPEG2000, oleic acid, and soy lecithin are displayed in Figure 1. The presence of a peak at 722 $\mathrm{cm}^{-1}$ in Figure 1(c) was attributed to the C-H groups of alkanes in oleic acid (Singh et al. 2016). The peaks around $1100 \mathrm{~cm}^{-1}$ were the characteristic peak for stretching in $\mathrm{C}-\mathrm{C}, \mathrm{C}-\mathrm{O}$, and $\mathrm{C}=\mathrm{O}$ bonds as well as bending vibration in C-C and C-O bonds (Chylińska et al. 2016; Muthukumaran \& Philip 2016). The band at $1146 \mathrm{~cm}^{-1}$ in Figure 1(a) was the main characteristic of polyethylene glycol (PEG) molecules (Deygen \& Kudryashova 2016), which can be further used for determination either it was related to trans conformation or gauche conformation with respective to $\mathrm{C}-\mathrm{C}$ bond while the asymmetric $\mathrm{PO}_{2}^{-}$stretching region can be observed by the peak at $1240 \mathrm{~cm}^{-1}$ (Varga et al. 2013). The significant peak around $1700 \mathrm{~cm}^{-1}$ was due to the presence of stretching vibration at the $\mathrm{C}=\mathrm{O}$ bond in all materials (Singh et al. 2016; Varga et al. 2013). The peaks around $2800-3000 \mathrm{~cm}^{-1}$ arose from the symmetric and asymmetric stretching vibrations of $\mathrm{C}-\mathrm{H}$ bands of the methylene groups (Muthukumaran \& Philip 2016). The characteristic broad band between 3000 and $3500 \mathrm{~cm}^{-1}$ was credited to the strong intramolecular hydrogen bonding and $\mathrm{O}-\mathrm{H}$ stretching vibration of water vapour (Soares et al. 2016). 


\section{Determination of Glass Transition Temperature, $T g$}

Thermogram of oleic acid, DOPE-PEG2000, and soy lecithin in Figure 2 shows the strong gel to the liquid transition temperature, $T_{g}$, where liquid crystalline was formed as an effect of melting at the non-polar hydrocarbon tail of surfactant. At these temperatures, the samples lost their glass-like properties (Crompton 2006) and became a viscous flexible rubbery state at $T_{g}$. During this transition, the stress relaxation where Young's and shear modulus, specific heat, the coefficient of expansion, and dielectric constant were changed abruptly. Unsaturated fatty acid, oleic acid had the glass transition temperature at $-4.3^{\circ} \mathrm{C}$ hence appeared as a viscous liquid in the room temperature. However, soy lecithin showed a blunt $T_{g}$ peak which was comparable with the result reported by Vijayakumar et al. (2016) that formed by the crystal transition of carbonhydrogen molecules in soy lecithin chain. Table 1 presented the glass transition temperature $\left(T_{g}\right)$ of oleic acid, DOPEPEG2000, and soy lecithin. Information on $T_{g}$ is important in the preparation of liposomes as they are formed at this temperature.

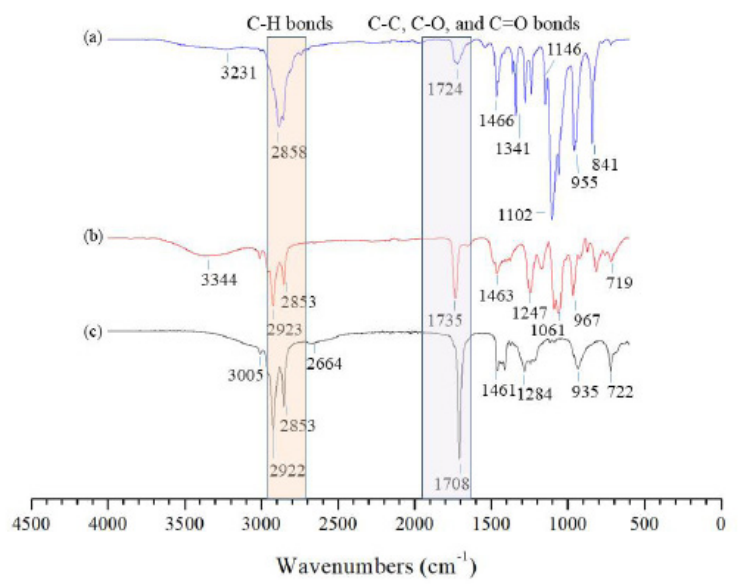

FIGURE 1. FTIR spectra of DOPEPEG2000 (a), lecithin (b), and oleic acid (c) at $30^{\circ} \mathrm{C}$

\section{Particle Size Distribution Analysis}

Analysis of the particle size of liposomes is crucial in controlling the compatibility for intravenous delivery (within the range of $4000 \mathrm{~nm}$ ) (Zhang et al. 2011), bioavailability, and uptake (Paini et al. 2015) of the encapsulated compounds into different cells. Figure 3 shows the size distribution of oleic acid liposomes, oleic acid-lecithin liposomes, and PEGylated oleic acid-lecithin liposomes (POLL), which was measured by employing dynamic light scattering method and calculated using Stokes-Einstein relationship at $30^{\circ} \mathrm{C}$. At pH7.4, oleic acid liposomes displayed a smallest average hydrodynamic size of $650.1 \mathrm{~nm}$ with polydispersity index values of 0.487 , followed by POLL, and oleic acid-lecithin liposomes at 1102.3 and $1768.2 \mathrm{~nm}$, respectively. Cis double bond in
C-18 oleic acid chain enhances the curvature of the bilayer through bends and kinks hence produce a smaller size liposomes in order to minimize the free energy of the system (Kanicky \& Shah 2002). Oleic acid-lecithin liposomes gave a greater size as a result of multilamellar liposomes formation as well as the presence of glycolipids groups attached with esterified sugar (Eh Suk \& Misran 2017; Zhao et al. 2015) as shown in the inset micrograph. An optimum amount of DOPEPEG2000 in the formulation will reduce the average diameter of liposomes (Eh Suk \& Misran 2016) as exhibited by POLL. Polydispersity index was significantly reduced from 1.000 in oleic acid-lecithin liposomes to 0.538 in POLL. Inset micrograph in Figure 3 confirmed the presence of PEGylated oleic acid-lecithin liposomes by birefringence effect in light phase and Maltese cross in the dark phase of the optical polarizing micrograph.

\section{Zeta Potential Analysis}

Negatively charged liposomes will ensure their biocompatibility as most of the cell membranes bear negative charges (Ciani et al. 2007). Table 2 shows the zeta potential determination of liposomes which also affected the electrophoretic mobility and conductivity of liposomal dispersion in PBS pH7.4 at reported temperature. Zeta potential values of oleic acid liposomes, oleic acid-lecithin liposomes, and POLL were $-62.3 \pm 2.6,-41.1 \pm 1.9$, and $-18.0 \pm 1.0 \mathrm{mV}$, respectively. Zeta potential was successfully reduced by more than $70 \%$ to be suitable with red blood cells which are $-14 \mathrm{mV}$. The presence of PEGylated lipid in the formulation will further reduce the clearance of liposomes by providing a stealth coating to POLL (Levchenko et al. 2002).

\section{ENCAPSULATION EFFICIENCY (\%EE) OF ANTICANCER DRUG}

Figure 4 displays the encapsulation efficiency percentage of different anticancer drugs either in the aqueous inner part or within the bilayer membrane of oleic acid liposomes, oleic acid-lecithin liposomes, and POLL (Naeem et al. 2016). More than $75 \%$ of individually encapsulated folinic acid, methotrexate, doxorubicin, and irinotecan were successfully loaded in the liposomes. This will protect them from denaturing and enhance the therapeutic effect at the targeted site (Paini et al. 2015). An intermediate Log P doxorubicin showed the highest encapsulation efficiency in all three formulations as compared to the other three anticancer drugs. With $\log \mathrm{P}$ at +0.53 , doxorubicin has a strong potential to be exhibited in both bilayer and aqueous compartment (Nii \& Ishii 2005). Folinic acid owing a Log $\mathrm{P}$ of -2.67 was predicted to locate at the aqueous compartment of liposomes (Gulati et al. 1998), showed more than $80 \% \mathrm{EE}$ in all formulations. However, the encapsulation efficiency of anticancer drugs was also governed by other factors such as liposomes properties, 
(a)

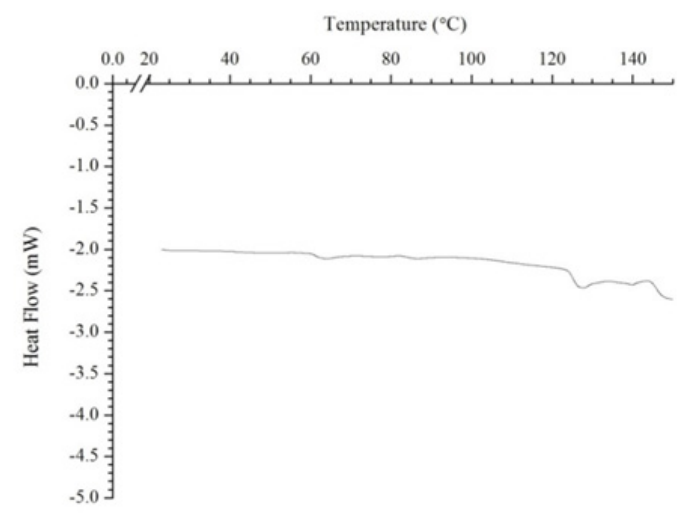

(b)

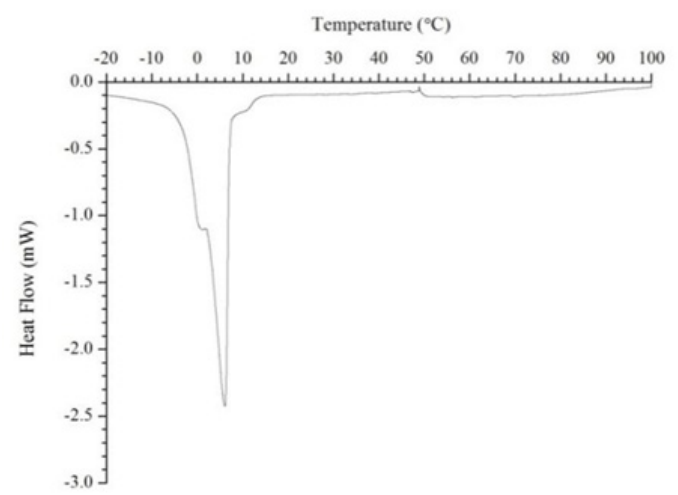

(c)

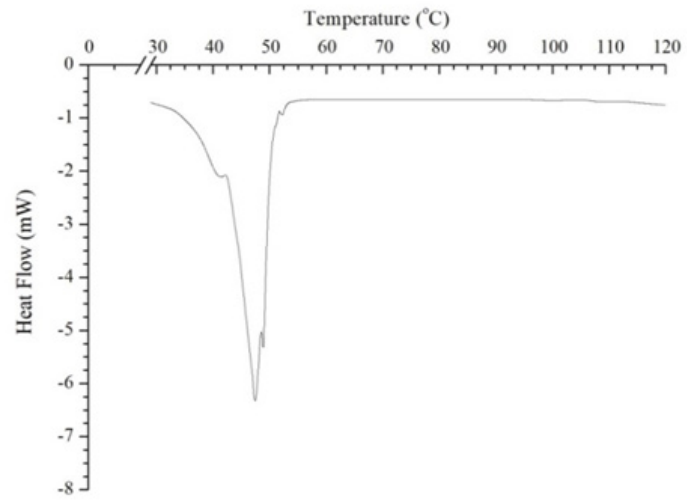

FIGURE 2. Differential scanning calorimetry (DSC) thermogram of lecithin (a), oleic acid (b), and DOPEPEG2000 (c)

TABLE 1. Glass transition temperatures, $T_{\mathrm{g}}$, of oleic acid, soy lecithin, and DOPEPEG2000

\begin{tabular}{lcccccc}
\hline \multicolumn{1}{c}{ Sample } & \multicolumn{3}{c}{ Glass transition temperature, $T_{\mathrm{g}}\left({ }^{\circ} \mathrm{C}\right)$} & \multicolumn{2}{c}{ Melting temperature } \\
& $T_{\mathrm{g}}$ onset & $T_{\mathrm{g}}$ inflection & $T_{\mathrm{g}}$ midpoint & $T_{\mathrm{g}}$ half width & Peak temperature $\left({ }^{\circ} \mathrm{C}\right)$ & Heat flow $(\mathrm{mW})$ \\
\hline Oleic acid & -4.3 & -2.4 & -2.5 & -3.4 & 6.2 & -2.0 \\
Soy Lecithin & 33.0 & 33.4 & 33.7 & 33.4 & 80.9 & -0.1 \\
DOPEPEG2000 & 36.8 & 38.6 & 39.2 & 38.0 & 48.7 & -6.1 \\
\hline
\end{tabular}

aqueous volume, membrane rigidity, surface area, and preparation methods.

\section{Evaluation OF Half MAXimal INHIBITORY Concentration, $I C_{50}$}

The MTT assay is one of the most used in vitro toxicology test (Boeckel et al. 2014; Yang et al. 2015), that is important to establish the safety limit of exposure to anticancer drugs, and evaluate the efficacy of the drugs or formulations against the desired effect (Frazier 1992). The blank POLL showed cytocompatibility with the A549, showing that it is ideal for drug delivery applications. Antitumor potential of POLL individually encapsulating anticancer drugs (folinic acid, methotrexate, doxorubicin, or irinotecan) were evaluated in A549 human lung cancer cell. Formation of formazan at the healthy viable cells by water-soluble tetrazolium salt was quantified using a multi-mode microplate reader.
The half maximal inhibitory concentrations, $I C_{50}$, of folinic acid, methotrexate, doxorubicin, and irinotecan in POLL were lower when compared to their free drugs (Figure 5). With increasing the exposure time, the $I C_{50}$ values were not reduced, likely due to the presence of fatty acid in the formulation that enhanced the growth of the cell. However, generally, $I C_{50}$ of folinic acid, methotrexate, and irinotecan in POLL was significantly lower as compared to their free drugs. This suggests that the POLL was remarkably effective in inhibiting the growth of the A549 cells (Ishida et al. 2001; Sun et al. 2015).

\section{Conclusion}

PEGylated oleic acid-lecithin liposomes (POLL) were prepared using soy lecithin and oleic acid, stabilized by DOPEPEG2000 without any intervention of external energy or mechanical procedures. Investigation of the thermograms of oleic acid, soy lecithin, and DOPEPEG2000 provide the 


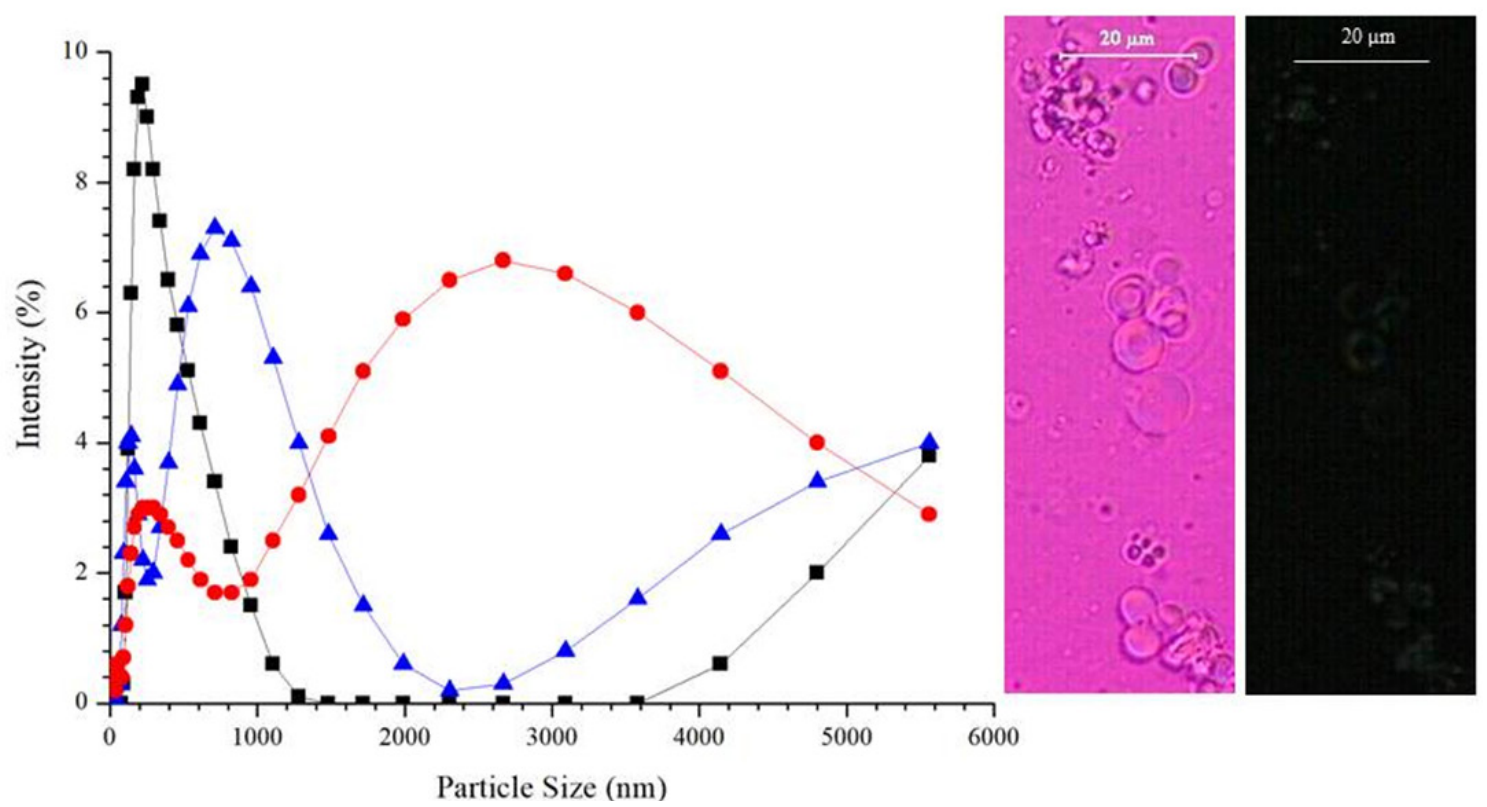

FIGURE 3. The average particle size of one-day-old oleic acid liposomes ( $\mathbf{\square})$, lecithin-oleic acid liposomes $(\mathbf{O})$, and PEGylated oleic acid-lecithin liposomes $(\boldsymbol{\Delta})$ prepared in PBS pH7.4 at 30 ${ }^{\circ} \mathrm{C}$. Inset micrographs are PEGylated oleic acid-lecithin liposomes viewed using light phase (a) and dark phase (b) optical polarizing microscope (OPM) at room temperature. Scales are $20 \mu \mathrm{m}$

TABLE 2. Zeta potential, mobility, and conductivity of one-day-old oleic acid liposomes, lecithin-oleic acid liposomes, and PEGylated oleic acid-lecithin liposomes (POLL) prepared in PBS $\mathrm{pH} 7.4$ at $30^{\circ} \mathrm{C}$

\begin{tabular}{lccc}
\hline Liposomes & Zeta potential $(\mathrm{mV})$ & Mobility $\left(\mu \mathrm{mcm} \mathrm{Vs}^{-1}\right)$ & Conductivity $\left(\mathrm{mS} \mathrm{cm}^{-1}\right)$ \\
\hline Oleic acid & $-62.3 \pm 2.6$ & $-5.3 \pm 0.2$ & $17.2 \pm 0.4$ \\
Oleic Acid - lecithin & $-41.1 \pm 1.9$ & $-3.5 \pm 0.2$ & $18.5 \pm 0.9$ \\
POLL & $-18.0 \pm 1.0$ & $-1.5 \pm 0.1$ & $15.8 \pm 0.9$ \\
\hline
\end{tabular}
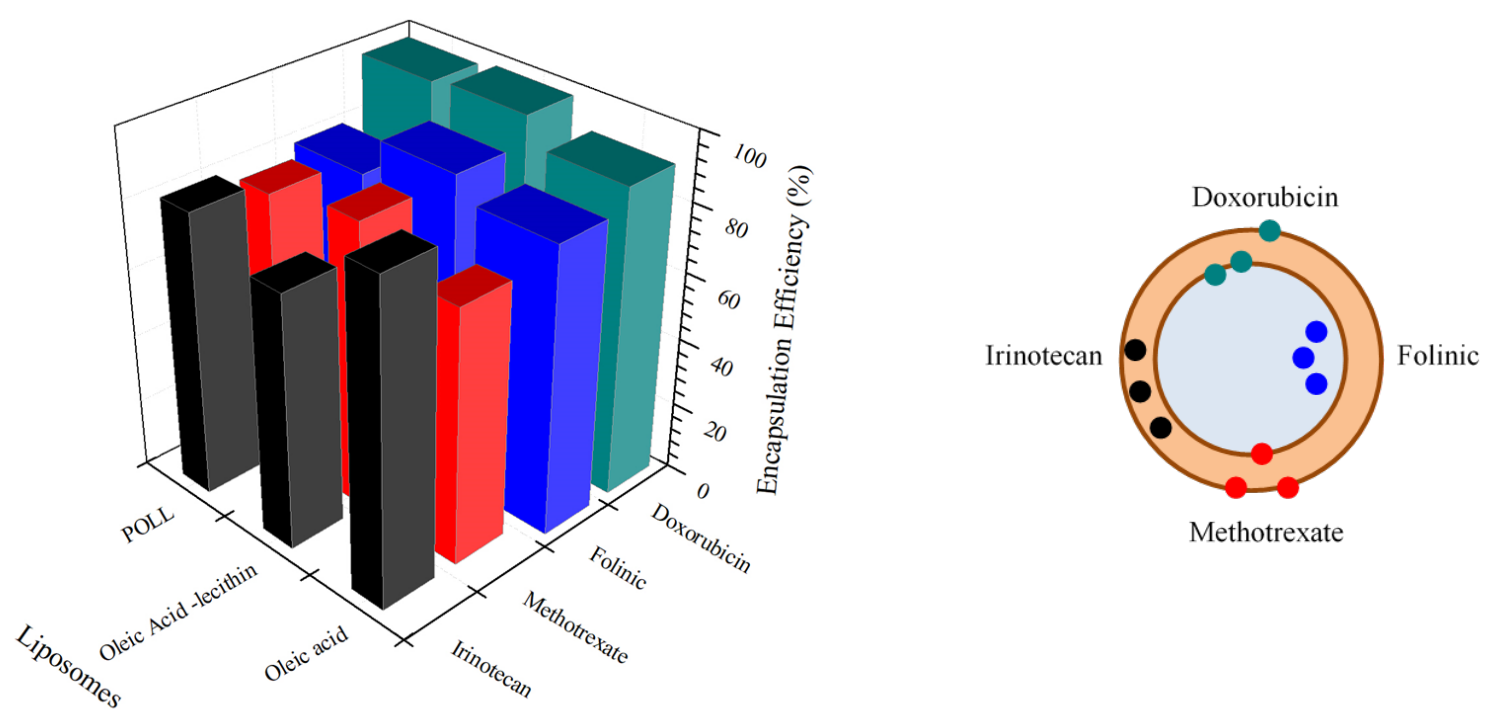

Methotrexate

FIGURE 4. Encapsulation efficiency (left) and distribution of anticancer drugs (right) in oleic acid liposomes, oleic acid-lecithin liposomes, and PEGylated oleic acid-lecithin liposomes (POLL) liposomes prepared in PBS pH7.4 at $30^{\circ} \mathrm{C}$ 
information on the minimum temperature that needed to produce oleic acid liposomes, oleic acid-lecithin liposomes, and POLL. The average hydrodynamic diameter of POLL was $37.7 \%$ reduced from oleic acid-lecithin liposomes. The morphological study using OPM exposed that liposomes were spherical in shape and lamellarity. Zeta potential value was successfully reduced to close to the zeta potential of the red blood cell. Anticancer drugs namely folinic acid, methotrexate, doxorubicin, and irinotecan hydrochloride were individually loaded into oleic acid liposomes, oleic acid-lecithin liposomes, and POLL with yielded more than $75 \%$ encapsulation efficiency. In vitro toxicology test in human lung cancer cell A549 using MTT assay showed the $I C_{50}$ values were lower in POLL as compared to free anticancer drugs. This suggests that POLL may be effective and show a high potential to be used as the vehicle for anticancer drugs.

\section{ACKNOWLEDGEMENTS}

The authors would like to thank friends from Colloid Lab, Department of Chemistry, members of Translational Core Laboratory, Faculty of Medicine, and UM, who provided insight and expertise that greatly assisted the research. This work was financially supported by the Prototype Research Grant Scheme (PRGS) (PR002-2018A), Geran Penyelidikan Fakulti GPF065B-2018, and Fundamental Research Grant Scheme (FRGS) (FP075-2018A).

\section{REFERENCES}

Anderson, W., Kozak, D., Coleman, V. A., Jämting, A. K. \& Trau, M. 2013. A comparative study of submicron particle sizing platforms: Accuracy, precision and resolution analysis of polydisperse particle size distributions. Journal of Colloid and Interface Science 405: 322-330.

Bae, Y. H., Mrsny, R. J. \& Park, K. 2013. Cancer Targeted Drug Delivery: An Elusive Dream. New York: Springer.

Banerjee, R., Tyagi, P., Li, S. \& Huang, L. 2004. Anisamidetargeted stealth liposomes: A potent carrier for targeting doxorubicin to human prostate cancer cells. Int. J. Cancer https://doi.org/10.1002/ijc.20452.

Bansal, D., Gulbake, A., Tiwari, J. \& Jain, S. K. 2016. Development of liposomes entrapped in alginate beads for the treatment of colorectal cancer. International Journal of Biological Macromolecules 82: 687-695.

Beaglehole, R., Bonita, R. \& Magnusson, R. 2011. Global cancer prevention: An important pathway to global health and development. Public Health 125(12): 821-831.

Boeckel, D. G., Shinkai, R. S. A., Grossi, M. L. \& Teixeira, E.R. 2014. In vitro evaluation of cytotoxicity of hyaluronic acid as an extracellular matrix on OFCOL II cells by the MTT assay. Oral Surgery, Oral Medicine, Oral Pathology and Oral Radiology 117(6): e423-e428.

Bray, F. \& Shield, K. D. 2017. Cancer: Global burden, trends, and projections. International Encyclopedia of Public Health. 2nd ed. Oxford: Academic Press. pp. 347-368.

Chun, S. G., Skinner, H. D. \& Minsky, B. D. 2017. Radiation therapy for locally advanced esophageal cancer. Surgical

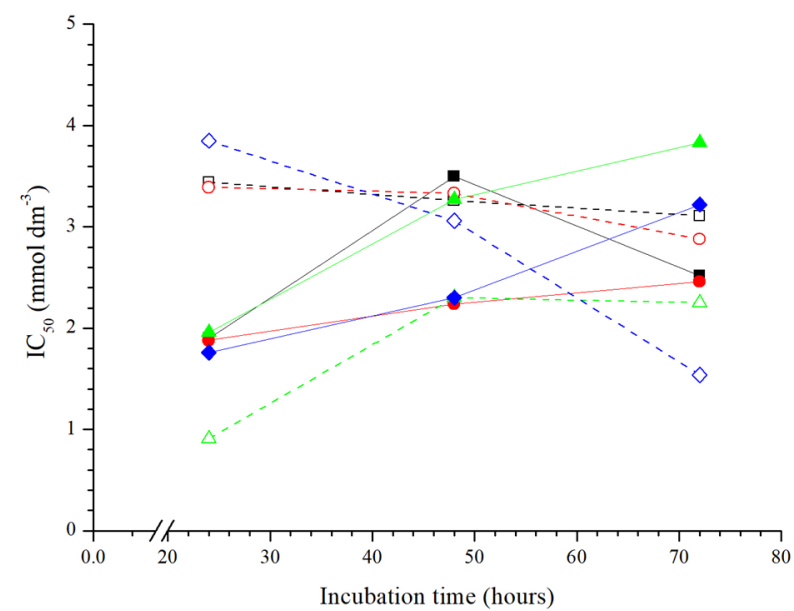

FIGURE 5. The half-maximal inhibitory concentration, $I C_{50}$, of PEGylated oleic acid-lecithin liposomes (POLL) encapsulating folinic acid ( $\square$ ), methotrexate (O), doxorubicin ( $\Delta$ ), and irinotecan $(\nabla)$ at $37^{\circ} \mathrm{C}$. Open symbols represent $I C_{50}$ values of free anticancer drugs, respectively

Oncology Clinics of North America 26(2): 257-276.

Chylińska, M., Szymańska-Chargot, M. \& Zdunek, A. 2016. FT-IR and FT-Raman characterization of non-cellulosic polysaccharides fractions isolated from plant cell wall. Carbohydrate Polymers 154: 48-54.

Ciani, L., Ristori, S., Bonechi, C., Rossi, C. \& Martini, G. 2007. Effect of the preparation procedure on the structural properties of oligonucleotide/cationic liposome complexes (lipoplexes) studied by electron spin resonance and Zeta potential. Biophysical Chemistry 131(1-3): 80-87.

Crompton, T. R. 2006. Polymer Reference Book. Rapra Technology Limited.

Deygen, I. M. \& Kudryashova, E. V. 2016. New versatile approach for analysis of PEG content in conjugates and complexes with biomacromolecules based on FTIR spectroscopy. Colloids and Surfaces B: Biointerfaces 141: 36-43.

Dollinger, M., Tempero, M. \& Mulvihill, S. 2002. Everyone's Guide to Cancer Therapy: How Cancer Is Diagnosed, Treated, and Managed Day to Day. 4th ed. Kansas: Andrews McMeel Publishing.

Duh, Y. S., Lee, C. Y., Chen, Y. L. \& Kao, C.S. 2016. Characterization on the exothermic behaviors of cathode materials reacted with ethylene carbonate in lithium-ion battery studied by differential scanning calorimeter (DSC). Thermochimica Acta 642: 88-94.

Eh Suk, V. R. \& Misran, M. 2017. Preparation, characterization and physicochemical properties of DOPE-PEG2000 stabilized oleic acid-soy lecithin liposomes (POLL). Colloids and Surfaces A: Physicochemical and Engineering Aspects 513: 267-273.

Eh Suk, V. R. \& Misran, M. 2016. Development and characterization of DOPEPEG2000 coated oleic acid liposomes encapsulating anticancer drugs. Journal of Surfactants and Detergents 20(2): 321-329.

Fameau, A. L., Arnould, A. \& Saint-Jalmes, A. 2014. Responsive self-assemblies based on fatty acids. Current Opinion in Colloid \& Interface Science 19(5): 471-479.

Feng, Z., Wen, H., Bi, R., Yang, W. \& Wu, X. 2016. Prognostic impact of the time interval from primary surgery to 
intravenous chemotherapy in high grade serous ovarian cancer. Gynecologic Oncology 141(3): 466-470.

Frazier, J. M. 1992. In-Vitro Toxicity Testing: Applications to Safety Evaluation. Boca Raton: CRC Press.

Gebicki, J. M. \& Hicks, M. 1973. Ufasomes are stable particles surrounded by unsaturated fatty acid membranes. Nature 243(5404): 232-234.

Gulati, M., Grover, M., Singh, S. \& Singh, M. 1998. Lipophilic drug derivatives in liposomes. International Journal of Pharmaceutics 165(2): 129-168.

Gupta, M., Sharma, V. \& Chauhan, N. S. 2017. Nanotechnology for oral delivery of anticancer drugs: An insight potential A2-Andronescu, Ecaterina. In. Nanostructures for Oral Medicine, edited by Andronescu, E. \& Grumezescu, A. Elsevier. pp. 467-510.

Hamzah, M. A. A. M., Aruldass, C. A., Ahmad, W. A. \& Setu, S. A. 2017. Effects of surfactants on antibacterial drugs-A brief review. Malaysian Journal of Fundamental and Applied Sciences 13(2): 118-123.

Heshmat, M. \& Eltawil, A. 2017. A new sequential approach for chemotherapy treatment and facility operations planning. Operations Research for Health Care 18: 33-40.

Hsu, W. H., Liu, S. Y., Chang, Y. J., Chang, C. H., Ting, G. \& Lee, T. W. 2014. The PEGylated liposomal doxorubicin improves the delivery and therapeutic efficiency of $188 \mathrm{Re}-$ Liposome by modulating phagocytosis in $\mathrm{C} 26$ murine colon carcinoma tumor model. Nuclear Medicine and Biology 41(9): 765-771.

Immordino, M. L., Franco, D. \& Cattel, L. 2006. Stealth liposomes: Review of the basic science, rationale, and clinical applications, existing and potential. International Journal of Nanomedicine 1(3): 297-315.

Ishida, T., Kirchmeier, M. J., Moase, E. H., Zalipsky, S. \& Allen, T. M. 2001. Targeted delivery and triggered release of liposomal doxorubicin enhances cytotoxicity against human B lymphoma cells. Biochimica et Biophysica Acta (BBA) - Biomembranes 1515(2): 144-158.

Jøraholmen, M. W., Basnet, P., Acharya, G. \& Škalko-Basnet, N. 2017. PEGylated liposomes for topical vaginal therapy improve delivery of interferon alpha. European Journal of Pharmaceutics and Biopharmaceutics 113: 132-139.

Kanicky, J. R. \& Shah, D. O. 2002. Effect of degree, type, and position of unsaturation on the $\mathrm{pKa}$ of long-chain fatty acids. Journal of Colloid and Interface Science 256(1): 201-207.

Lai, K. W. \& Dewi, D. E. O. 2015. Medical Imaging Technology: Reviews and Computational Applications. Singapore: Springer Singapore.

Lasic, D.D. 1992. Mixed micelles in drug delivery. Nature 355: 279-280.

Lehtinen, J., Magarkar, A., Stepniewski, M., Hakola, S., Bergman, M., Róg, T., Yliperttula, M., Urtti, A. \& Bunker, A. 2012. Analysis of cause of failure of new targeting peptide in PEGylated liposome: Molecular modeling as rational design tool for nanomedicine. European Journal of Pharmaceutical Sciences 46(3): 121-130.

Levchenko, T. S., Rammohan, R., Lukyanov, A. N., Whiteman, K. R. \& Torchilin, V. P. 2002. Liposome clearance in mice: The effect of a separate and combined presence of surface charge and polymer coating. International Journal of Pharmaceutics 240(1-2): 95-102.

Lewis, H. L. \& Bloomston, M. 2016. Hepatic artery infusional chemotherapy. Surgical Clinics of North America 96(2): 341-355.

Martinez-Pastor, B. \& Mostoslavsky, R. 2012. Sirtuins, metabolism, and cancer. Frontiers in Pharmacology 3: 22.

Mehta, S. K. \& Jindal, N. 2013. Mixed micelles of lecithintyloxapol as pharmaceutical nanocarriers for anti-tubercular drug delivery. Colloids and Surfaces B: Biointerfaces 110: 419-425.

Menon, P., Yin Yin, T. \& Misran, M. 2015. Preparation and characterization of liposomes coated with DEAEDextran. Colloids and Surfaces A: Physicochemical and Engineering Aspects 481: 345-350.

Muthukumaran, T. \& Philip, J. 2016. Effect of phosphate and oleic acid capping on structure, magnetic properties and thermal stability of iron oxide nanoparticles. Journal of Alloys and Compounds 689: 959-968.

Naeem, S., Kiew, L. V. \& Chung, L. Y. 2016. Liposomes as amphiphilic carriers: Encapsulation and stability aspects. Sains Malaysiana 45(1): 71-77.

Napia, L. M. A., Rahman, I. A., Hamzah, M.Y., Mohamed, F., Mohd, H. M. K., Bastamam, I. S. A., Sharin, S., Hidzir, N. M. \& Radiman, S. 2018. Effect of gamma irradiation on the physical stability of DPPC liposomes. Sains Malaysiana 47(6): 1235-1240.

Nii, T. \& Ishii, F. 2005. Encapsulation efficiency of watersoluble and insoluble drugs in liposomes prepared by the microencapsulation vesicle method. International Journal of Pharmaceutics 298(1): 198-205.

Ninomiya, K., Yamashita, T., Tanabe, Y., Imai, M., Takahashi, K. \& Shimizu, N. 2016. Targeted and ultrasound-triggered cancer cell injury using perfluorocarbon emulsionloaded liposomes endowed with cancer cell-targeting and fusogenic capabilities. Ultrasonics Sonochemistry 28: 5461.

Ohnishi, N., Yamamoto, E., Tomida, H., Hyodo, K., Ishihara, H., Kikuchi, H., Tahara, K. \& Takeuchi, H. 2013. Rapid determination of the encapsulation efficiency of a liposome formulation using column-switching HPLC. International Journal of Pharmaceutics 441(1-2): 67-74.

Paini, M., Daly, S. R., Aliakbarian, B., Fathi, A., Tehrany, E. A., Perego, P., Dehghani, F. \& Valtchev, P. 2015. An efficient liposome based method for antioxidants encapsulation. Colloids and Surfaces B: Biointerfaces 136: 1067-1072.

Sercombe, L., Veerati, T., Moheimani, F., Wu, S. Y., Sood, A. K. \& Hua, S. 2015. Advances and challenges of liposome assisted drug delivery. Frontiers in Pharmacology 6: 286. https://doi.org/10.3389/fphar.2015.00286.

Singh, V. K., Pandey, P. M., Agarwal, T., Kumar, D., Banerjee, I., Anis, A. \& Pal, K. 2016. Development of soy lecithin based novel self-assembled emulsion hydrogels. Journal of the Mechanical Behavior of Biomedical Materials 55: 250-263.

Soares, P. I. P., Laia, C. A. T., Carvalho, A., Pereira, L. C. J., Coutinho, J. T., Ferreira, I. M. M., Novo, C. M. M. \& Borges, J. P. 2016. Iron oxide nanoparticles stabilized with a bilayer of oleic acid for magnetic hyperthermia and MRI applications. Applied Surface Science 383: 240-247.

Stevenson-Abouelnasr, D., Husseini, G. A. \& Pitt, W. G. 2007. Further investigation of the mechanism of doxorubicin release from P105 micelles using kinetic models. Colloids and Surfaces B: Biointerfaces 55(1): 59-66.

Sun, L., Zhou, D. S., Zhang, P., Li, Q.H. \& Liu, P. 2015. 
Gemcitabine and $\gamma$-cyclodextrin/docetaxel inclusion complex-loaded liposome for highly effective combinational therapy of osteosarcoma. International Journal of Pharmaceutics 478(1): 308-317.

Suzuki, T., Ichihara, M., Hyodo, K., Yamamoto, E., Ishida, T., Kiwada, H., Ishihara, H. \& Kikuchi, H. 2012. Accelerated blood clearance of PEGylated liposomes containing doxorubicin upon repeated administration to dogs. International Journal of Pharmaceutics 436(1-2): 636643.

Tan, H. W. \& Misran, M. 2013. Polysaccharide-anchored fatty acid liposome. International Journal of Pharmaceutics 441(1-2): 414-423.

Teo, Y. Y., Misran, M., Low, K. H. \& Zain, S. M. 2011. Effect of unsaturation on the stability of $\mathrm{C} 18$ polyunsaturated fatty acids vesicles suspension in aqueous solution. Bulletin of the Korean Chemical Society 32(1): 59-64.

Varga, Z., Mihály, J., Berényi, S. \& Bóta, A. 2013. Structural characterization of the poly(ethylene glycol) layer of sterically stabilized liposomes by means of FTIR spectroscopy. European Polymer Journal 49(9): 24152421.

Vijayakumar, M. R., Kosuru, R., Vuddanda, P. R., Singh, S. K. \& Singh, S. 2016. Trans resveratrol loaded DSPE PEG 2000 coated liposomes: An evidence for prolonged systemic circulation and passive brain targeting. Journal of Drug Delivery Science and Technology 33: 125-135.

Vlasova, M. A., Rytkönen, J., Riikonen, J., Tarasova, O. S., Mönkäre, J., Kovalainen, M., Närvänen, A., Salonen, J., Herzig, K. H., Lehto, V. P. \& Järvinen, K. 2014. Nanocarriers and the delivered drug: Effect interference due to intravenous administration. European Journal of Pharmaceutical Sciences 63: 96-102.

Vorbeck, C. S., Vogelius, I. R., Banner-Voigt, M. L. V. C., Mathiesen, H. F. \& Mirza, M. R. 2017. Survival and failure types after radiation therapy of vulvar cancer. Clinical and Translational Radiation Oncology 5: 20-27.

Xu, Z. X. J. 2013. New Concept and New Way of Treatment of Cancer. Indiana: AuthorHouse.

Yang, Y., Lu, Y., Wu, Q. Y., Hu, H. Y., Chen, Y. H. \& Liu, W. L.
2015. Evidence of ATP assay as an appropriate alternative of MTT assay for cytotoxicity of secondary effluents from WWTPs. Ecotoxicology and Environmental Safety 122: 490-496.

Yom, S. S. 2015. Radiation treatment of head and neck cancer. Surgical Oncology Clinics of North America 24(3): 423436.

Zhang, T., Li, Y. \& Mueller, A. 2011. Phase structure of liposome in lipid mixtures. Chemistry and Physics of Lipids 164(8): $722-726$.

Zhao, L., Temelli, F., Curtis, J. M. \& Chen, L. 2015. Preparation of liposomes using supercritical carbon dioxide technology: Effects of phospholipids and sterols. Food Research International 77(1): 63-72.

Zofka, A., Board, N. R. C. T. R. \& Program, S. S. H. R. 2013. Evaluating Applications of Field Spectroscopy Devices to Fingerprint Commonly Used Construction Materials. Washington, D.C.: Transportation Research Board.

Vicit Rizal Eh Suk* \& Misni Misran

Colloid Laboratory

Department of Chemistry

Faculty of Science, University of Malaya

50603 Kuala Lumpur, Federal Territory

Malaysia

Ivy Chung

Department of Pharmacology

Faculty of Medicine, University of Malaya

50603 Kuala Lumpur, Federal Territory

Malaysia

*Corresponding author; email: vicitrizal@um.edu.my

Received: 6 March 2019

Accepted: 8 October 2019 